\title{
Pengaruh Perhatian Orang tua, Budaya Sekolah, dan Teman Sebaya Terhadap Karakter Religius Anak
}

\author{
Christiani Purwaningsih ${ }^{1}{ }^{凶}$, Amir Syamsudin ${ }^{1}$ \\ Pendidikan Anak Usia Dini, Universitas Negeri Yogyakarta, Indonesia(1) \\ DOI: $10.31004 /$ obsesi.v6i4.2051
}

\begin{abstract}
Abstrak
Perkembangan karakter religius anak dipengaruhi berbagai faktor, seperti: perhatian orang tua, budaya sekolah, dan pergaulan teman sebaya. Tujuan penelitian untuk menganalisis pengaruh perhatian orang tua, budaya sekolah, dan pergaulan teman sebaya terhadap karakter religius anak. Pendekatan penelitian menggunakan penelitian kuantitatif. Jumlah sampel penelitian 267 orang tua anak di 28 TK di Kecamatan Ceper Klaten tahun pelajaran 2021/2022. Teknik pengambilan sampel menggunakan proportional random sampling. Teknik pengumpulan data dengan angket dan studi pustaka (dokumentasi). Teknik analisis data menggunakan regresi linier berganda. Hasil penelitian menyimpulkan: (1) secara parsial perhatian orang tua, budaya sekolah, dan pergaulan teman sebaya memiliki pengaruh positif dan signifikan terhadap karakter religius anak; (2) secara simultan perhatian orang tua, budaya sekolah, dan pergaulan teman sebaya memiliki kontribusi sebesar 58,2\% mempengaruhi karakter religius anak. Oleh karena itu, keberhasilan pembentukan karakter religius anak, perlu dilakukan secara terpadu dengan melibatkan tripusat pendidikan, yaitu: keluarga, sekolah, dan masyarakat.
\end{abstract}

Kata kunci : perhatian orang tua; budaya sekolah; pergaulan teman sebaya; karakter religius anak.

\begin{abstract}
The development of children religious character is influenced by various factors, such as: parental attention, school culture, and peer relationships. The purpose of study was to analyze the effect of parental attention, school culture, and peer relationships on the religious character. The research approach uses quantitative research. The number of research samples was 267 parents of children in 28 kindergartens in Ceper Klaten District for the 2020/2021 academic year. The sampling technique used proportional random sampling. Data collection techniques by questionnaires and literature study. The data analysis technique used multiple linear regression. The results of the study concluded: (1) partially parental attention, school culture, and peer relationships have a positive and significant influence on the religious character of children; (2) simultaneously parental attention, school culture, and peer relationships have contributed $58.2 \%$ to affect the religious character of children. Therefore, the success of forming a child's religious character needs to be carried out in an integrated manner by involving the three educational centers, namely: family, school, and community.
\end{abstract}

Keywords: parental attention; school culture; peer association; children's religious character.

Copyright (c) 2022 Christiani Purwaningsih, Amir Syamsudin

$\square$ Corresponding author:

Email Address : purwaningsihchristiani@gmail.com (Yogyakarta, Indonesia)

Received 13 October 2021, Accepted 4 January 2022, Published 17 January 2022 


\section{PENDAHULUAN}

Masa usia dini merupakan masa penting dimana pada masa ini ada era yang dikenal dengan masa keemasan (golden age). Masa keemasan hanya terjadi satu kali dalam perkembangan kehidupan manusia. Menurut Suprayeki, saat usia dini (the golden age) merupakan masa yang sangat kritis untuk pembenukan karakter anak. Oleh karena itu pembentukan karakter di mulai sedini mungkin pada anak (Nafsia \& Supena, 2020). Taja, Inten, \& Hakim menjelaskan bahwa usia dini merupakan fase pembentukan kepribadian yang tepat untuk ditanamkan nilai-nilai kebaikan ke dalam jiwa setiap anak (Shabrina et al., 2020).

Santrock menyatakan perkembangan anak usia dini mencakup aspek perkembangan fisik, kognitif, sosial-emosional, konteks sosial, moral, bahasa, identitas diri, dan gender (Sit, 2015). Suryana nejelaskan bahwa anak harus distimulasi bukan hanya dari segi kognitif, tetapi fisik motorik, bahasa, sosial emosional dan moral agama (Suharni, 2021).

Berdasarkan pendapat tersebut, maka salah satu perkembangan yang harus dikembangkan pada anak usia dini adalah nilai moral. Ellemers, van der Toorn, Paunov, \& van Leeuwen menjelaskan bawa moral dapat diartikan sebagai tata perilaku kebiasaaan sesuai norma masyarakat atau lingkungan yang berhubungan dengan baik ataupun buruk. Moralitas merupakan jalan yang "benar" dan "salah" dalam berperilaku, misalnya, ketika seseorang harus adil dan tidak adil. (Mukarromah et al., 2021).

Nilai moral ini berkaitan dengan karakter religius. Religius (keberagamaan) menilik pada aspek yang ada dalam hati nurani terdalam pribadi, sikap personal yang sebagian menjadi misteri bagi orang lain, karena menapaskan intimitas jiwa, cita rasa yang mencakup totalitas ke dalam pribadi manusia, dan bukan pada aspek yang bersifat formal (Muhaimin, 2018). Thanissaro menjelskan agama dapat menjadi motor penggerak dalam membangun spiritual, moral, sosial, dan kultural melalui pembelajaran non-kurikuler yang melibatkan orang tua dan guru yang berperan sebagai teladan dan sebagai pembimbing anak didik. (Towoliu \& Hartati, 2021).

Berdasarkan pengamatan dan wawancara dengan guru TK di tiga sekolah diperoleh informasi bahwa karakter religius anak harus ditanamkan sejak dini, karena karakter religius berkaitan dengan agama yang dapat menjadi fondasi bagi anak dalam berperilaku. Karakter religius anak perlu dikembangkan karena umumnya anak belum banyak mengenal agama yang dianutnya, belum dapat menjalankan ibadah sesuai ajaran agamanya, ada anak yang kurang bersikap sopan terhadap orang yang lebih tua, dan ada anak yang seringkali menggangu temannya.

Karakter religius sebagai nilai karakter yang berkaitan dengan hubungan dengan Tuhan yang meliputi: pikiran, perkataan, dan tindakan seseorang yang diupayakan selalu berdasarkan pada nilai-nilai ketuhanan dan/atau ajaran agamanya (Gunawan, 2014). Masdalipah, menjelaskan bahwa usia dini merupakan saat yang tepat untuk meletakkan dasar-dasar dari aspek perkembangan anak, salah satu aspek perkembangan yang harus dikembangkan dalam diri anak adalah aspek nilai agama dan moral (Wahyuni \& Purnama, 2021). Koesoema menjelaskan bahwa pendidikan karakter bertujuan untuk menanamkan nilai-nilai kebaikan serta tidak hanya memiliki kepandaian dalam berfikir tetapi juga respek terhadap lingkungan dan melatih potensi diri anak agar dapat berkembang kearah yang positif (Apriliani et al., 2021). Purwanti menambahkan karakter berkaitan dengan kepedulian, kejujuran, keadilan, tanggung jawab, dan rasa hormat terhadap diri dan orang lain bersama dengan nilai-nilai kinerja pendukungnya seperti ketekunan, etos kerja yang tinggi, kerja keras, dan kegigihan (Shabrina et al., 2020).

Hasil penelitian Trimuliana \& Dhieni (2019) menyimpulkan bahwa anak usia 5-6 tahun memiliki perilaku religius yang terlihat dalam kebiasaan sehari-hari anak seperti membiasakan diri untuk mengucap dan membalas salam, berdoa sebelum dan sesudah kegiatan, menghafal surat-surat pendek Al-Qur'an, belajar praktek wudhu' dan sholat, bersedekah untuk orang yang kurang mampu, mendoakan kedua orang tua dan sesama muslim. 
Karakter religius anak dapat dipengaruhi oleh lingkungan keluarga, sekolah dan lingkungan masyarakat. Hal ini seperti yang dijelaskan oleh Sriwilujeng bahwa ada tiga pihak yang dapat mendukung terbentuknya karakter religius yaitu keluarga, sekolah dan lingkungan (Sriwilujeng, 2017). Hal ini karena menurut Elfindri lingkungan kehidupan merupakan pengaruh yang sangat kuat dalam pembentukan karakter. Jika lingkungan kehidupan dinilai negatif maka akan memberikan hasil negatif pula (Elfindri, 2012). Scarr menambahkan bahwa semua anak berhak atas lingkungan yang dapat mengembangkan potensi-potensi mereka sampai ke tingkat yang terbaik dan membuat mereka menjadi orangorang yang bahagia (Sarwono, 2013).

Pendidikan anak usia dini adalah suatu upaya yang diberikan orang dewasa kepada anak sejak lahir hingga usia 6 tahun dengan berbagai stimulasi untuk membantu pertumbuhan dan perkembangannya secara optimal. Mulai usia 2 atau 3 tahun hingga 6 tahun anak mulai mengenal lingkungan lain di luar keluarganya yaitu lingkungan sekolah. Di dalam lingkungan tersebut anak mengenal dirinya, temannya, orang dewasa di sekitarnya, serta lingkungannya (Rohita, 2021)

Lingkungan berperan besar dalam pendidikan karakter anak, karena hal ini sesuai konsep tripusat pendidikan berasal dari istilah yang dipakai Ki Hajar Dewantara dalam memberdayakan semua unsur masyarakat untuk membangun pendidikan. Menurut Fadil dan Triyo menambahkan bahwa yang tripusat pendidikan adalah setiap pribadi anak akan mengalami perkembangan dalam tiga lembaga, yaitu keluarga, sekolah, dan masyarakat (Fadil \& Triyo, 2017). Hasil penelitian Prasanti \& Fitriani (2018) menyimpulkan bahwa proses pembentukan karakter anak usia dini, diawali dari keluarga, kemudian dilanjutkan dengan sekolah, dan komunitas yang diikuti anak usia dini tersebut.

Lingkungan pertama yang dianggap berpengaruh terhadap karakter religius anak adalah lingkungan keluarga. Jalaluddin menjelaskan bahwa lingkungan keluarga merupakan pendidikan yang pertama dimana anak mendapatkan pengetahuan dan pemahaman tentang agama dari orang tua, sehingga pendidikan yang paling banyak diterima oleh anak adalah dalam keluarga (Jalaluddin, 2018). Diadha menambahkan bahwa peran orang tua sangat diperlukan dalam pendidikan anak, selain untuk memantau perkembangan anak, juga bisa untuk menanamkan nilai-nilai baik yang sudah diterapkan di sekolah untuk kemudian dilanjutkan di rumah (Putri et al., 2020).

Hasil penelitian Firmansyah (2020) menyimpulkan bahwa terdapat pengaruh positif dan signifikan perhatian orangtua terhadap peningkatan akhlak anak. Penelitian Dedih et al. (2019) menyimpulkan bahwa perhatian orang tua dalam pendidikan keagamaan di rumah memiliki korelasi positif dengan perilaku anak di sekolah. Hasil penelitian Mukarromah et al. (2021) menyimpulkan bahwa gaya pengasuhan dan pengasuhan dari keluarga khususnya orang tua memiliki keterkaitan dengan perkembangan moral anak. Hasil penelitian Utami \& Prasetyo (2021) menyimpulkan bahwa terdapat hubungan pengasuhan yang diberikan orang tua terhadap pembentukan karakter disiplin anak.

Lingkungan kedua yang dianggap berpengaruh terhadap perkembangan karakter religius anak adalah lingkungan sekolah. Lingkungan sekolah berkaitan dengan budaya sekolah. Sahlan menjelaskan bahwa budaya sekolah yang baik pada hakikatnya merupakan terwujudnya nilai-nilai ajaran agama sebagai tradisi dalam berperilaku dan budaya organisasi yang diikuti oleh seluruh warga sekolah (Sahlan, 2016). Marini menjelaskan bahwa nilai-nilai karakter dapat diintegrasikan tidak hanya di dalam kelas tetapi juga di dalam budaya sekolah (Yarmi \& Wardhani, 2020). Abdullah menambahkan bahwa sekolah ramah anak merupakan upaya perbaikan organisasi sekolah yang menekankan pada kesehatan fisik dan mental anakanak serta memiliki kendali penuh atas anak dan lingkungan untuk menciptakan lingkungan belajar yang tepat, tanpa kekerasan, pelecehan dan menjaga martabat anak ( $\mathrm{Na}^{\prime}$ imah \& Widyasari, 2020).

Hasil penelitian Silkyanti (2019) menyimpulkan bahwa budaya sekolah religius dapat berperan dalam membentuk karakter pada siswa. Hasil penelitian Nuraeni \& Nurunnisa 
(2020) menyimpulkan bahwa peningkatan karakter anak usia dini secara nyata dipengaruhi oleh adanya program sekolah ramah anak. Hasil penelitian (Na'imah \& Widyasari, 2020) menyimpulkan bahwa optimalisasi karakter anak dapat dilakukan dengan mengembangkan manajemen sekolah dan budaya sekolah yang menjamin keamanan fisik dan psikologis anak.

Lingkungan ketiga yang dianggap berpengaruh terhadap karakter religius anak adalah lingkungan sosial (masyarakat). Sani dan Kadri menjelaskan lingkungan masyarakat mempunyai peran yang penting karena setiap peserta didik juga hidup di kalangan masyarakat yang bermacam-macam akhlak dan sifatnya, dimana apabila lingkungannya itu baik akhlaknya, maka baik pula akhlak para peserta didik, tetapi sebaliknya apabila lingkungannya itu buruk akhlaknya, maka tidak menutup kemungkinan akan buruk pula akhlak para peserta didik tersebut (Sani \& Kadri, 2016). Papalia, Sally, Old, dan Ruth menjelaskan ketika anak berinterkasi dengan lingkungan sosial berbasis budaya lokal anak mampu membangun pemahaman dan pengetahuan tentang dunia sebagai hasil dari tindakan-tindakan anak dengan lingkungan mereka (Nafsia \& Supena, 2020).

Hasil penelitian Ramadhani \& Fauziah (2020) menyimpulkan bahwa hubungan teman sebaya yang positif akan meningkatkan prestasi perkembangan sosial dan emosional anakanak Hasil penelitian Desiani (2020) menyimpulkan bahwa teman sebaya memiliki peran dalam membentuk berbagai karakter siswa, yaitu, toleransi, disiplin, kerja keras, rasa ingin tahu, peduli sosial, peduli lingkungan, membangkang, dan agresif.

Pengaruh lingkungan sosial ada yang diterima secara langsung seperti dalam pergaulan sehari-hari dengan orang lain yang tidak langsung melalui radio dan televisi, dengan membaca buku, majalah dan berbagai cara yang lain (Purwanto, 2016). Pengaruh lingkungan masyarakat terhadap anak dapat dilihat dari pergaulan teman sebaya. Menurut Santrock pergaulan teman sebaya adalah anak-anak atau remaja yang memiliki usia atau tingkat kematangan yang kurang lebih sama (Santrock, 2017).

Anak usia prasekolah mulai memiliki teman bermain, serta memiliki aktivitas yang teratur di luar lingkungan rumah. Kesadaran akan ada dunia lain di sekitarnya, mulai membuat anak menyesuaikan emosi dan perilakunya agar dapat ikut masuk dalam pergaulan teman sebayanya (Anjelina et al., 2020). Ananda dan Fadhilaturrahmi menjelaskan bahwa proses sosial sangat diperlukan dalam belajar kelompok karena anak berhubungan dengan teman sebaya sehingga anak harus dapat mengontrol emosinya (Izza, 2020). Yu et al. menjelaskan bahwa membangun persahabatan adalah tujuan penting dari perkembangan sosial anak usia dini. Persahabatan bermanfaat bagi anak dengan menciptakan rasa memiliki dan rasa aman, serta dapat mengurangi stres (Ramadhani \& Fauziah, 2020).

Penelitian sekarang memiliki perbedaan dengan penelitian sebelumnya. Firmansyah, (2020) dan Dedih et al. (2019) hanya menghubungkan perhatian orang tua dengan karakter anak. Penelitian Silkyanti (2019) menghubungkan budaya sekolah dengan karakter anak. Penelitian Desiani (2020) menghubungkan teman sebaya dengan karakter anak. Penelitian sekarang mencoba menghubungkan tripusat pendidikan (perhatian orang tua, budaya sekolah dan teman sebaya) dengan karakter anak. Sebenarnya sudah ada peneliti sebelumnya Prasanti \& Fitriani (2018) yang mencoba meneliti keterkaitan tripusat pendidikan dengan karakter anak, yang berjudul "Pembentukan Karakter Anak Usia Dini: Keluarga, Sekolah, dan Komunitas?", namun pendekatan penelitian yang digunakan adalah penelitian kualitatif, sedangkan penelitian sekarang menggunakan pendekatan kuantitatif.

\section{METODOLOGI}

Populasi adalah peserta didik tahun pelajaran 2021/2022 di 28 lembaga yang ada di Kecamatan Ceper Kabupaten Klaten yang berjumlah 806 anak. Sampel dihitung dengan rumus Slovin pada presisi 5\% dan diperoleh jumlah sampel sebanyak 267 orang tua anak. Teknik sampling menggunakan probability sampling. Teknik pengumpulan data adalah penyebaran angket dan studi pustaka (dokumentasi). Sebelum kuesioner digunakan untuk mengumpulkan data, dilakukan uji validitas isi oleh dua ahli (judgement) berdasarkan indeks 
Aiken's dan item kuesioner dinyatakan valid. Selanjutnya berdasarkan uji empiris, kuesioner dinyatakan valid, karena korelasi item dengan total item memiliki koefisien > 0,3 dan reliabel karena koefisien Cronbach Alpha > 0,7. Teknik analisis data menggunakan: uji asumsi klasik yang meliputi uji normalitas, heteroskedastisitas, dan multikolinieritas sebagai persyaratan uji regresi, serta analisis regresi linier berganda untuk membuktikan hipotesis. Pengaruh setiap variabel independen terhadap variabel dependen dinyatakan signifikan, apabila $p$-value < 0,05 .

\section{HASIL DAN PEMBAHASAN}

\section{Perhatian Orang Tua}

Skor tertinggi kuesioner perhatian orang tua adalah 35 dan terendah 14. Menurut Hadi (2016) skor perhatian orang tua dapat dikelompokkan menjadi 3 kelas/kelompok, yaitu rendah, sedang, dan tinggi, sebagaimana pada tabel 1.

Tabel 1 Kategori Skor Perhatian Orang Tua

\begin{tabular}{cccc}
\hline Skor & Kategori & Jumlah & Persentase \\
\hline $14-21$ & Rendah & 6 & 2,25 \\
$22-28$ & Sedang & 49 & 18,35 \\
$29-35$ & Tinggi & 212 & 79,40 \\
\hline & Jumlah & 267 & 100,00 \\
\hline
\end{tabular}

Pada tabel 1 diketahui bahwa dari 267 responden ada 6 orang tua murid (2,25\%) memberikan perhatian kepada anaknya dalam kategori rendah (kurang), sebanyak 49 orang tua murid (18,35\%) memberikan perhatian kepada anaknya dalam kategori sedang (cukup), dan sebanyak 212 orang tua murid $(79,40 \%)$ memberikan perhatian kepada anaknya dalam kategori tinggi. Dari temuan ini dapat dikatakan bahwa sebagain besar orang tua memberikan perhatian kepada anaknya.

\section{Budaya Sekolah}

Skor tertinggi kuesioner budaya sekolah adalah 55 dan skor terendah adalah 22 Dari skor tersebut kemudian dapat dibuat pengelompokkan skor menurut tinggi, sedang, dan rendah seperti ditampilkan pada tabel 2.

Tabel 2 Kategori Skor Budaya Sekolah

\begin{tabular}{cccc}
\hline \multicolumn{1}{c}{ Skor } & Kategori & Jumlah & Persentase \\
\hline $22-33$ & Rendah & 3 & 1,12 \\
$34-44$ & Sedang & 6 & 2,25 \\
$45-55$ & Tinggi & 258 & 96,63 \\
\hline \multicolumn{2}{c}{ Jumlah } & 267 & 100,00 \\
\hline
\end{tabular}

Pada tabel 2 diketahui bahwa dari 267 responden ada sebanyak 3 orang tua murid $(1,12 \%)$ mengatakan bahwa budaya sekolah anaknya adalah rendah (kurang), sebanyak 6 orang tua murid (2,25\%) mengatakan bahwa budaya sekolah anaknya adalah sedang (cukup), dan sebanyak 258 orang tua murid $(96,63 \%)$ mengatakan bahwa budaya sekolah anaknya adalah tinggi. Dari temuan ini dapat dikatakan bahwa sebagian besar orang tua murid mengatakan bahwa budaya sekolah anaknya adalah sangat baik (tinggi) untuk pengembangan karakter anak. 


\section{Pergaulan Teman Sebaya}

Skor tertinggi adalah 65 dan skor terendah adalah 21. Berdasarkan skor tersebut kemudian dapat dibuat pengelompokkan skor menurut tinggi, sedang, dan rendah seperti ditampilkan seperti pada tabel 3.

Tabel 3 Kategori Skor Pergaulan Teman Sebaya

\begin{tabular}{|c|c|c|c|}
\hline Skor & Kategori & Jumlah & Persentase \\
\hline $21-36$ & Rendah & 7 & 2,62 \\
\hline $37-50$ & Sedang & 74 & 27,72 \\
\hline $51-65$ & Tinggi & 186 & 69,66 \\
\hline \multicolumn{2}{|c|}{ Jumlah } & 267 & 100,00 \\
\hline
\end{tabular}

Pada tabel 3 diketahui bahwa dari 267 responden terdapat 7 orang tua murid $(2,62)$ mengatakan bahwa pergaulan anaknya dengan teman sebaya adalah rendah (kurang), ada 74 orang tua murid $(27,72 \%)$ mengatakan bahwa pergaulan anaknya dengan teman sebaya adalah sedang (cukup), dan sebanyak 186 orang tua murid $(69,66 \%)$ mengatakan bahwa pergaulan anaknya dengan teman sebaya adalah tinggi (baik). Dari temuan ini dapat dikatakan bahwa sebagian besar orang tua murid mengatakan bahwa pergaulan anaknya dengan teman sebaya adalah tinggi (baik).

\section{Karakter Religius Anak}

Skor tertinggi kuesioner karakter religius anak adalah 65 dan skor terendah adalah 26. Berdasarkan skor tersebut kemudian dapat dibuat pengelompokkan skor menurut tinggi, sedang, dan rendah seperti rumus di atas, dan hasilnya ditampilkan pada tabel 4 .

Tabel 4. Kategori Skor Karakter Religius Anak

\begin{tabular}{cccc}
\hline Skor & Kategori & Jumlah & Persentase \\
\hline $26-39$ & Rendah & 12 & 4,49 \\
$40-52$ & Sedang & 119 & 44,57 \\
$53-65$ & Tinggi & 136 & 50,94 \\
\hline \multicolumn{2}{c}{ Jumlah } & 267 & 100,00 \\
\hline
\end{tabular}

Pada tabel 4 diketahui bahwa dari 267 responden ada 12 orang tua murid $(4,49 \%)$ mengatakan bahwa anaknya memiliki karakter religius dengan kategori rendah (kurang), ada 119 orang tua murid $(44,57 \%)$ mengatakan bahwa anaknya memiliki karakter religius dengan kategori sedang (cukup), dan 136 orang tua murid (50,94\%) mengatakan bahwa anaknya memiliki karakter religius dengan kategori tinggi (baik). Dari temuan ini dapat dikatakan bahwa sebagain besar orang tua murid mengatakan bahwa anaknya memiliki karakter religius dengan kategori tinggi (baik).

\section{Uji Asumsi Klasik}

\section{Uji Multikolinieritas}

Uji multikolinieritas untuk menguji apakah pada model regresi ditentukan adanya korelasi antar variabel independen. Berdasarkan uji multikolinieriotas didapatkan hasil sebagaimana ditampilkan pada tabel 5 . Hasil uji multikolinieritas di atas diketahui besarnya VIF masing-masing variabel lebih kecil dari 10 dan memiliki nilai tolerance lebih besar dari 0,1, sehingga dapat disimpulkan tidak terdapat multikolinieritas. Dengan kata lain, antara variabel perhatian orang tua, budaya sekolah, dan pergaulan teman sebaya tidak memiliki hubungan yang kuat, sehingga hal ini tidak mengganggu model regresi yang ditetapkan. 
Pengaruh Perhatian Orang tua, Budaya Sekolah, dan Teman Sebaya Terhadap Karakter Religius Anak DOI: 10.31004/obsesi.v6i4.2051

Tabel 5 Hasil Uji Multikolinieritas

\begin{tabular}{llll}
\hline & & \multicolumn{2}{c}{ Collinearity Statistics } \\
Model & & Tolerance & VIF \\
\hline 1 & (Constant) &, 715 & \\
& perhatian_ortu &, 673 & 1,399 \\
& budaya_sklh &, 628 & 1,486 \\
& teman_sebaya &, 628 & 1,592 \\
\hline
\end{tabular}

\section{Uji Heteroskedastisitas}

Uji heteroskedastisitas untuk menguji apakah dalam sebuah model regresi terjadi ketidaksamaan varians dari residual dari satu pengamatan ke pengamatan yang lain. Berdasarkan uji heteroskedastisitas dengan uji Glejser diperoleh hasil sebagaimana pada tabel 6.

Tabel 6 Hasil Uji Glejser Coefficients $^{a}$

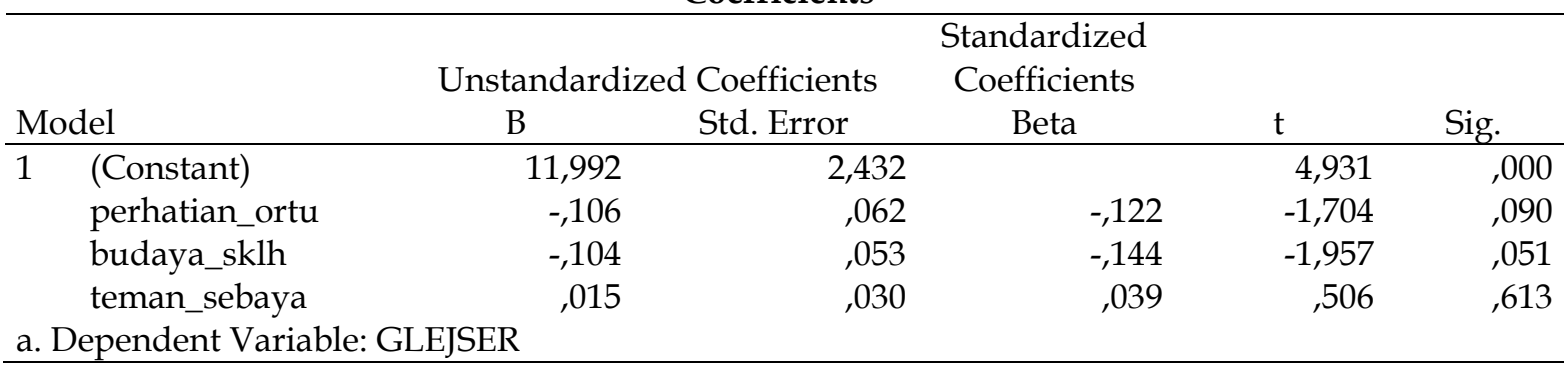

Pada tabel 6 terlihat bahwa perhatian orang tua memiliki signifikansi 0,090 >0,05, budaya sekolah memiliki signifikansi $0,051 \geq 0,05$ dan pergaulan teman sebaya memiliki signifikansi 0,613 >0,05. Mengingat hasil signifikansi untuk budaya sekolah pada ambang batas 0,05, maka dilakukan uji lanjutan dengan Uji Park dengan cara mengubah skor variabel bebas menjadi Log Natural (LN) dan mengkuadratkan unstandardized residual, dan hasilnya seperti disajikan pada tabel 7 .

Tabel 7 Hasil Uji Park

Coefficients $^{\mathrm{a}}$

\begin{tabular}{|c|c|c|c|c|c|c|}
\hline \multirow{2}{*}{\multicolumn{2}{|c|}{ Model }} & \multicolumn{5}{|c|}{ Standardized } \\
\hline & & B & Std. Error & Beta & $\mathrm{t}$ & Sig. \\
\hline 1 & (Constant) & 299,676 & 95,374 & & 3,142 & ,002 \\
\hline & LN_perhatian & $-8,110$ & 22,898 &,- 026 &,- 354 & ,723 \\
\hline & LN budaya & $-58,713$ & 30,613 &,- 151 & $-1,918$ & 056 \\
\hline & LN teman & $-3,260$ & 19,318 &,- 013 & -169 & 866 \\
\hline
\end{tabular}

a. Dependent Variable: Kuadrat_res

Pada tabel 7 terlihat bahwa perhatian orang tua memiliki signifikansi 0,723 $>0,05$, budaya sekolah memiliki signifikansi 0,056 > 0,05 dan pergaulan teman sebaya memiliki signifikansi 0,856 > 0,05. Hal ini dapat disimpulkan bahwa untuk data perhatian orang tua, budaya sekolah, dan pergaulan teman sebaya dengan karakter religius anak tidak terjadi permasalahan heteroskedastisitas pada model regresi.

\section{Uji Normalitas}

Uji normalitas dimaksudkan untuk mengetahui bahwa apakah dalam sebuah model regresi, variabel dependen, variabel independen atau keduanya mempunyai distribusi normal 
ataukah tidak. Berdasarkan hasil uji normalitas dengan Kolmogorov-Smirnov diperoleh hasil pada tabel 8 .

Tabel 8. Hasil Uji Normalitas dengan Kolmogorov-Smirnov

\begin{tabular}{llr}
\hline \multicolumn{2}{c}{ One-Sample Kolmogorov-Smirnov Test } & $\begin{array}{c}\text { Unstandardized } \\
\text { Residual }\end{array}$ \\
& & 267 \\
$\mathrm{~N}$ & Mean &, 0000000 \\
Normal Parametersa,b & Std. Deviation & 5,10976676 \\
& Absolute &, 053 \\
Most Extreme Differences &, 044 \\
& Positive &,- 053 \\
& Negative &, 053 \\
Test Statistic & &, $069 c$ \\
Asymp. Sig. (2-tailed) & \\
a. Test distribution is Normal. & \\
b. Calculated from data. & \\
c. Lilliefors Significance Correction. & \\
\hline
\end{tabular}

Pada tabel 8 terlihat bahwa nilai signifikansi diperoleh 0,069>0,05. Dengan demikian, data residual terdistribusi normal, sehingga data penelitian memenuhi persyaratan analisis data dengan regresi.

\section{Uji Hipotesis}

Analisis Regresi Linier Berganda

Hasil analisis regresi linier berganda disajikan pada tabel 9.

Tabel 9. Hasil Regresi Linier Berganda

Coefficients ${ }^{\mathrm{a}}$

\begin{tabular}{|c|c|c|c|c|c|}
\hline \multirow[b]{2}{*}{ Model } & \multicolumn{5}{|c|}{ Standardized } \\
\hline & $\mathrm{B}$ & Std. Error & Beta & $\mathrm{t}$ & Sig. \\
\hline $1 \quad$ (Constant) & $-1,947$ & 4,034 & &,- 483 & ,630 \\
\hline perhatian_ortu & ,407 & 103 & 185 & 3,946 & 000 \\
\hline budaya_sklh & 207 & 088 & 113 & 2,345 & ,020 \\
\hline teman_sebaya &, 575 & ,049 & ,585 & 11,695 & 000 \\
\hline
\end{tabular}

a. Dependent Variable: Karakter_religius

Berdasarkan hasil analisis Regresi Linier Berganda didapatkan persamaan regresi sebagai berikut:

$$
Y=-1,947+0,407 X_{1}+0,0207 X_{2}+0,575 X_{3}
$$

Dari persamaan garis regresi itu dapat dijelaskan sebagai berikut ini; 1) Nilai konstanta menunjukkan angka -1,947. Artinya tanpa ada pengaruh variabel perhatian orang tua, budaya sekolah, dan pergaulan teman sebaya, maka skor karakter religius anak adalah -1,947 atau sangat rendah. 2) Koefisien regresi perhatian orang tua menunjukkan angka positif 0,407, berarti variabel perhatian orang tua memiliki pengaruh positif terhadap karakter religius anak. 3) Koefisien regresi budaya sekolah menunjukkan angka positif 0,207, berarti variabel budaya sekolah memiliki pengaruh positif terhadap karakter religius anak. 4) Koefisien regresi pergaulan teman sebaya menunjukkan angka positif 0,575 , berarti variabel pergaulan teman sebaya memiliki pengaruh positif terhadap karakter religius anak. 


\section{Ujit}

Berdasarkan hasil uji t seperti terlihat pada tabel 9 di atas dapat dijelaskan sebagai berikut ini; 1) Hasil uji $t$ pengaruh perhatian orang tua terhadap karakter religius anak menunjukkan nilai thitung sebesar 3,946 dengan nilai signifikansi sebesar 0,000<0,05, maka dapat disimpulkan bahwa perhatian orang tua memiliki pengaruh positif dan signifikan terhadap karakter religius anak. 2) Hasil t-hitung pengaruh budaya sekolah terhadap karakter religius anak menunjukkan nilai t-hitung sebesar 2,345 dengan nilai signifikansi sebesar 0,020 $<0,05$, berarti budaya sekolah berpengaruh posiitif dan signifikan terhadap karakter religius anak. 3) Hasil t-hitung pengaruh pergaulan teman sebaya terhadap karakter religius anak menunjukkan nilai t-hitung sebesar 11,695 dengan nilai signifikansi sebesar 0,000<0,05, berarti pergaulan teman sebaya berpengaruh positif dan signifikan terhadap karakter religius anak.

\section{Uji F}

Uji $\mathrm{F}$ dimaksudkan untuk menguji signifikansi hasil perhitungan korelasi antara seluruh variabel bebas yaitu perhatian orang tua, budaya sekolah, dan pergaulan teman sebaya terhadap variabel tergantung yaitu karakter religius anak. Berdasarkan uji $\mathrm{F}$ didapatkan hasil seperti tabel di bawah ini.

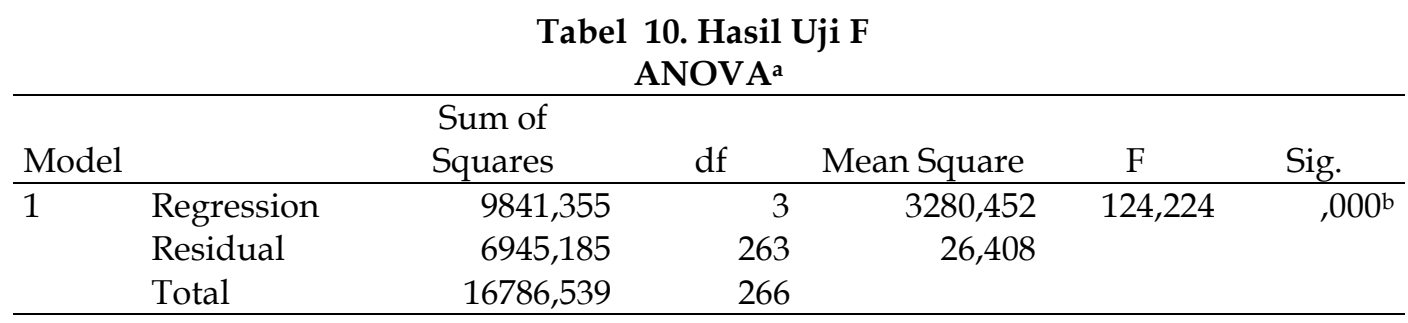

a. Dependent Variable: Karakter_religius

b. Predictors: (Constant), teman_sebaya, perhatian_ortu, budaya_sklh

Pada tabel 10 terlihat bahwa besarnya nilai $\mathrm{F}=124,224$ dengan signifikansi $0,000<0,05$, sehingga dapat disimpulkan bahwa secara bersama-sama variabel perhatian orang tua, budaya sekolah, dan pergaulan teman sebaya berpengaruh signifikan terhadap karakter religius anak.

\section{Uji Koefisien Determinasi}

Hasil uji koefisien determinansi disajikan pada tabel 11.

Tabel 11. Hasil Uji Koefisien Determinan Model Summary

\begin{tabular}{|c|c|c|c|c|}
\hline Model & $\mathrm{R}$ & R Square & Adjusted R Square & $\begin{array}{l}\text { Std. Error of the } \\
\text { Estimate }\end{array}$ \\
\hline 1 &, $766^{\mathrm{a}}$ &, 586 & ,582 & 5,13883 \\
\hline
\end{tabular}

Pada tabel 11 diketahui bahwa $\mathrm{R}^{2}$ (Adjusted $R$ square) didapatkan hasil sebesar 0,582 atau $58,2 \%$. Hal ini berarti secara bersama-sama variabel perhatian orang tua, budaya sekolah, dan pergaulan teman sebaya berpengaruh terhadap karakter religius anak sebesar $58,2 \%$ dan sisanya sebesar $41,8 \%$ dipengaruhi oleh variabel lain yang tidak diteliti.

\section{Pembahasan}

\section{Pengaruh Perhatian Orang Tua Terhadap Karakter Religius Anak}

Hasil penelitian menemukan bahwa perhatian orang tua memiliki pengaruh positif dan signifikan terhadap karakter religius anak. Jika perhatian orang tua ditingkatkan, maka 
karakter religius anak akan meningkat. Hasil penelitian ini mendukung penelitian Firmansyah (2020), yang menyimpulkan bahwa terdapat pengaruh positif dan signifikan perhatian orangtua terhadap peningkatan akhlak anak. Mendukung pula penelitian yang dilakukan oleh Dedih et al. (2019), yang menyimpulkan bahwa perhatian orang tua dalam pendidikan keagamaan di rumah memiliki korelasi positif dengan perilaku anak di sekolah.

Perhatian orang tua memiliki pengaruh psikologis yang kuat dalam kegiatan belajar anak. Peran orang tua dalam belajar anak dapat membimbing anaknya dalam pekerjaan rumahnya, dalam memotivasi belajar anaknya, dalam memantau perkembangan belajar anaknya. Ketika seorang anak mendapatkan perhatian penuh dari orang tuanya dalam belajar, anak cenderung akan giat dan sungguh-sungguh dalam belajarnya, sehingga hal tersebut dapat berpengaruh kepada prestasi belajarnya (Safitri \& Nurhayati, 2019).

Yusmanto dalam Safitri \& Nurhayati (2019) menjelaskan bahwa perhatian dari orang tua sangat membantu anak dalam peningkatan belajar di rumah maupun di sekolah, juga bermanfaat bagi perkembangan psikologis anak. Perhatian orang tua dapat berwujud tersedianya sarana dan prasarana belajar yang menjadikan anak lebih bersemangat dalam menjalankan aktivitas belajarnya. Selain itu menegur anak jika melakukan hal-hal yang kurang baik (melanggar norma-norma yang berlaku), dengan disertai suatu arahan dan bimbingan kepada anak, sehingga anak menjadi baik. Menurut Sardiman dalam Safitri \& Nurhayati (2019) peran orang tua dalam belajar anak seharusnya dapat membimbing belajar anaknya, membimbing dalam pekerjaan rumahnya, memotivasi belajar anaknya, sehingga orang tua dapat memantau perkembangan belajar anaknya.

\section{Pengaruh Budaya Sekolah Terhadap Karakter Religius Anak}

Hasil penelitian menemukan bahwa budaya sekolah berpengaruh posiitif dan signifikan terhadap karakter religius anak. Jika budaya sekolah semakin baik, maka karakter religius anak akan meningkatkan. Hasil penelitian ini mendukung penelitian Silkyanti, (2019), yang menyimpulkan bahwa: 1) Budaya sekolah religius setiap harinya meliputi budaya senyum, salam, sapa, sopan dan santun atau 5S, do"a bersama, hafalan, TPQ, sholat dhuha dan sholat dhuhur. 2) Metode atau langkah dalam membentuk karakter melalui keteladanan dan pembiasaan. 3) Karakter yang dihasilkan adalah religius, disiplin, toleransi, bersahabat, dan tanggung jawab. Dalam penelitian tersebut menyatakan bahwa peran budaya sekolah religius dapat membentuk karakter pada siswa.

Budaya sekolah yang baik pada hakikatnya merupakan terwujudnya nlai nilai ajaran agama sebagai tradisi dalam berperilaku dan budaya organisasi yang diikuti oleh seluruh warga sekolah. Karena itu dengan menjadikan agama sebagai tradisi dalam sekolah maka secara sadar maupun tidak ketika warga sekolah mengikuti tradisi yang telah tertanam tersebut sebenarnya warga sekolah sudah melakukan ajaran agama (Sahlan, 2016).

Sahlan lebih lanjut menjelaskan bahwa untuk membentuk budaya sekolah yang baik dapat dilakukan melalui: (1) Memberikan contoh (teladan); (2) Membiasakan hal hal yang baik; (3) Menegakkan disiplin; (4) Memberikan motivasi dan dorongan; (5) Memberikan hadiah terutama psikologis; (6) Menghukum (mungkin dalam rangka kedisiplinan); (7) Penciptaan suasana religius yang berpengaruh bagi pertumbuhan anak (Sahlan, 2016).

Hasil pengembangan budaya sekolah yang baik tersebut untuk meningkatkan perilaku yang konsisten dan untuk menyampaikan kepada personil sekolah, terutama anak didik, tentang bagaimana perilaku yang seharusnya dilakukan untuk membangun kepribadian mereka dalam lingkungan sekolah yang sesuai dengan iklim lingkungan yang tercipta di sekolah baik itu lingkungan fisik maupun iklim kultur yang ada (Daryanto \& Tarno, 2015).

\section{Pengaruh Pergaulan Teman Sebaya Terhadap Karakter Religius Anak}

Hasil penelitian menemukan bahwa pergaulan teman sebaya berpengaruh positif dan signifikan terhadap karakter religius anak. Jika pergaulan teman sebaya ditingkatkan, maka 
karakter religius anak akan meningkatkan. Hasil penelitian ini mendukung hasil penelitian Desiani (2020), yang menyimpulkan bahwa teman sebaya memiliki peran dalam membentuk berbagai karakter siswa, yaitu, toleransi, disiplin, kerja keras, rasa ingin tahu, peduli sosial, peduli lingkungan, membangkang, dan agresif.

Teman sebaya adalah seseorang yang dapat membuat dirinya merasa lebih aman karena secara tidak langsung seorang teman akan melindungi temannya dari apapun yang dapat membahayakan temannya. Selain itu, sebuah pertemanan dapat dijadikan sebagai adanya hubungan untuk saling berbagi dalam suka ataupun duka, saling memberi dengan ikhlas, saling percaya, saling menghormati, dan saling menghargai. Perkembangan teman sebaya dengan pengaruh yang cukup kuat merupakan hal penting dalam masa-masa anakanak.

Hubungan teman sebaya yang positif akan meningkatkan prestasi perkembangan sosial dan emosional anak-anak. Bermain dengan teman sebaya dapat memberikan kesempatan bagi anak-anak untuk belajar berbagai hal, terutama belajar berinteraksi dengan orang lain dan mengendalikan emosi sehingga mereka dapat diterima oleh hubungan teman sebaya (Ramadhani \& Fauziah, 2020). Menurut Hay (2015) teman sebaya memainkan peran penting dalam kehidupan anak-anak pada titik perkembangan yang jauh lebih awal daripada yang diduga. Pengalaman dua atau tiga tahun pertama kehidupan berimplikasi pada penerimaan anak oleh teman sekelasnya di taman kanak-kanak dan tahun-tahun sekolah berikutnya. Anak-anak yang kompeten dengan teman sebaya pada usia dini, dan mereka yang menunjukkan perilaku prososial, kemungkinan besar akan diterima oleh teman sebayanya. Santrock mengemukakan bahwa salah satu fungsi terpenting dari kelompok teman sebaya adalah: (a) Sebagai sumber informasi mengenai dunia diluar keluarga; (b) Memperoleh umpan balik mengenai kemampuannya dari kelompok teman sebaya; (c) Mempelajari bahwa apa yang mereka lakukan itu lebih baik, sama baik atau kurang baik, dibandingkan anak-anak lainnya (Santrock, 2017).

\section{Pengaruh Perhatian Orang Tua, Budaya Sekolah, dan Pergaulan Teman Sebaya Terhadap Karakter Religius Anak}

Berdasarkan hasil penelitian disimpulkan bahwa perhatian orang tua, budaya sekolah, dan pergaulan teman sebaya berpengaruh teradap karakter religius anak, karena ketiga variabel tersebut berkaitan dengan tripusat pendidikan, yaitu: lingkungan keluarga (perhatian orang tua), lingkungan sekolah (budaya sekolah religius), dan lingkungan masyarakat (pergaulan teman sebaya). Hasil penelitian ini selaras dengan hasil penelitian (Prasanti \& Fitriani, 2018) yang menyimpulkan bahwa proses pembentukan karakter anak usia dini, diawali dari keluarga, kemudian dilanjutkan dengan sekolah, dan komunitas yang diikuti anak usia dini tersebut.

Fadil dan Triyo menjelaskan bahwa tripusat pendidikan adalah keluarga, sekolah, dan masyarakat. Ketiga lembaga ini secara bertahap dan terpadu mengemban tanggung jawab pendidikan bagi generasi mudanya (Fadil \& Triyo, 2017). Karakter religius sebagai sikap dan perilaku yang patuh dalam melaksanakan ajaran agama yang dianutnya, toleran terhadap pelaksanaan ibadah agama lain, dan hidup rukun dengan pemeluk agama lain (Suparlan, 2012).

Keluarga berpengaruh terhadap karakter religius anak selaras dengan hasil penelitian Firmansyah (2020); Dedih et al. (2019); Mukarromah et al. (2021); dan Utami \& Prasetyo (2021). Budaya sekolah berpengaruh terhadap karakter religius anak selaras dengan hasil penelitian Silkyanti (2019); Nuraeni \& Nurunnisa (2020); dan Na' imah \& Widyasari (2020). Teman sebaya berpengaruh terhadap karakter religius anak selaras dengan hasil penelitian Ramadhani \& Fauziah (2020); dan Desiani (2020).

Penelitian ini memiliki keterbatasan yaitu kuesioner diisi oleh orang tua siswa, sehingga jawaban yang diberikan kadang kurang mewakili keadaan sesungguhnya yang terjadi pada anaknya. Namun demikian, hasil penelitian ini memiliki makna bahwa 
keberhasilan pembentukan karakter religius anak, perlu dilakukan secara terpadu dengan melibatkan tripusat pendidikan, yaitu: keluarga, sekolah, dan masyarakat.

\section{SIMPULAN}

Perhatian orang tua memiliki pengaruh positif dan signifikan terhadap karakter religius anak. Budaya sekolah memiliki pengaruh positif dan signifikan terhadap karakter religius anak. Pergaulan teman sebayai memiliki pengaruh positif dan signifikan terhadap karakter religius anak. Secara bersama-sama perhatian orang tua, budaya sekolah dan pergaulan teman sebaya memiliki kontribusi sebesar 58,3\% mempengaruhi karakter religius anak. Oleh karena itu, keberhasilan pembentukan karakter religius anak, perlu dilakukan secara terpadu dengan melibatkan tripusat pendidikan, yaitu: keluarga, sekolah, dan masyarakat.

\section{UCAPAN TERIMA KASIH}

Peneliti mengucapkan terima kasih kepada kepala sekolah, guru dan orang tua anak yang telah berpartisipasi aktif membantu pengisian kuesioner.

\section{DAFTAR PUSTAKA}

Anjelina, L., Putri, D., Yetti, E., \& Hartati, S. (2020). Jurnal Obsesi : Jurnal Pendidikan Anak Usia Dini Pengaruh Keterlibatan Orangtua dan Regulasi Diri terhadap Perilaku Bullying Anak Usia Dini Abstrak. 4(1), 715-732. https://doi.org/10.31004/obsesi.v4i2.438

Apriliani, E. I., Purwanti, K. Y., \& Riani, R. W. (2021). Jurnal Obsesi : Jurnal Pendidikan Anak Usia Dini Peningkatan Kesantunan Bahasa Anak Usia Dini melalui Media Pembelajaran Interaktif Budaya Jawa Abstrak. 5(1), 150-157. https://doi.org/10.31004/obsesi.v5i1.319

Daryanto, \& Tarno. (2015). Impelemtasi pendidikan karakter di sekolah. Gava media.

Dedih, U., Zakiyah, Q. Y., \& Melina, J. O. (2019). Perhatian Orang Tua dalam Pendidikan Keagamaan Anak di Rumah Hubungannya dengan Perilaku Mereka di Lingkungan Sekolah. Atthulab: Islamic Religion Teaching and Learning Journal, 4(1), 1-23. https://doi.org/10.15575/ath.v4i1.2585

Desiani, T. (2020). Pengaruh Pergaulan Temman Sebaya terhadap Pembentukan Karakter Siswa Kelas VIII MTS Negeri 3 Kabupaten Tangerang. JM2PI: Jurnal Mediakarya Mahasiswa Pendidikan Islam, 1(1), 47-68.

Elfindri. (2012). Pendidikan Karakter: kerangka, metode dan aplikasi untuk pendidik dan profesional. Baduose media.

Fadil, M., \& Triyo, S. (2017). Sosiologi pendidikan. Sukses offset.

Firmansyah, A. (2020). Pengaruh Perhatian Orang Tua Terhadap Peningkatan Akhlak Anak. Alim | Journal of Islamic Education, 2(1), 139-150. https:// doi.org/10.51275/alim.v2i1.174

Gunawan, H. (2014). Pendidikan karakter konsep dan implementasi. Alfabeta.

Hay, D. F. (2015). Early peer relations and their impact on children's development. Cardiff university.

Izza, H. (2020). Jurnal Obsesi: Jurnal Pendidikan Anak Usia Dini Meningkatkan Perkembangan Sosial Anak Usia Dini melalui Metode Proyek Abstrak. 4(2), 951961. https:// doi.org/10.31004/obsesi.v4i2.483

Jalaluddin. (2018). Psikologi agama memahami perilaku dengan mengalikasikan prinsipprinsip psikologi. PT Raja grafindo persada.

Muhaimin. (2018). Paradigma pendidikan islam: upaya mengefektifkan pendidikan agama islam di sekolah. PT. Remaja rosdakarya. 
Mukarromah, T. T., Hafidah, R., \& Nurjanah, N. E. (2021). Jurnal Obsesi : Jurnal Pendidikan Anak Usia Dini Kultur Pengasuhan Keluarga terhadap Perkembangan Moral Anak Usia Dini Abstrak. 5(1), 395-403. https://doi.org/10.31004/obsesi.v5i1.550

Nafsia, A., \& Supena, A. (2020). Jurnal Obsesi: Jurnal Pendidikan Anak Usia Dini Pembentukkan Karakter Anak Usia Dini melalui Budaya Nalo di Kampung Lodo Abstrak. 4(2), 703-714. https:// doi.org/10.31004/obsesi.v4i2.439

Na'imah, T., \& Widyasari, Y. (2020). Jurnal Obsesi : Jurnal Pendidikan Anak Usia Dini Implementasi Sekolah Ramah Anak untuk Membangun Nilai-Nilai Karakter Anak Usia Dini Abstrak. 4(2), 747-756. https:// doi.org/10.31004/obsesi.v4i2.283

Nuraeni, L., \& Nurunnisa, R. (2020). Jurnal Obsesi : Jurnal Pendidikan Anak Usia Dini Efektivitas Program Sekolah Ramah Anak dalam Meningkatkan Karakter Anak Usia Dini Abstrak. 4(1), 20-29. https:// doi.org/10.31004/obsesi.v4i1.204

Prasanti, D., \& Fitriani, D. R. (2018). Pembentukan Karakter Anak Usia Dini: Keluarga, Sekolah, Dan Komunitas? (Studi Kualitatif tentang Pembentukan Karakter Anak Usia Dini Melalui Keluarga, Sekolah, dan Komunitas). 2(1), 13-19. https://doi.org/10.31004/obsesi.v2i1.2

Purwanto, N. (2016). Psikologi pendidikan. Remaja rosdakarya.

Putri, D. K., Handayani, M. C., \& Akbar, Z. (2020). Jurnal Obsesi : Jurnal Pendidikan Anak Usia Dini Pengaruh Media Pembelajaran dan Motivasi Diri terhadap Keterlibatan Orang Tua dalam Pendidikan Anak Abstrak. 4(2), 649-657. https:// doi.org/10.31004/obsesi.v4i2.418

Ramadhani, P. R., \& Fauziah, P. Y. (2020). Jurnal Obsesi : Jurnal Pendidikan Anak Usia Dini Hubungan Sebaya dan Permainan Tradisional pada Keterampilan Sosial dan Emosional Anak Usia Dini Abstrak. 4(1), 1011-1020. https://doi.org/10.31004/obsesi.v4i2.502

Rohita. (2021). Jurnal Obsesi : Jurnal Pendidikan Anak Usia Dini Pengenalan Covid-19 pada Anak Usia Prasekolah : Analisis pada Pelaksanaan Peran Orangtua di Rumah Abstrak. 5(1), 315-326. https://doi.org/10.31004/obsesi.v5i1.528

Safitri, L. N., \& Nurhayati. (2019). Pengembangan Nilai Agama dan Moral Melalui Metode Bercerita pada Anak. 1. https:// doi.org/10.14421/iga.2019.41-08

Sahlan, A. (2016). Mewujudkan budaya religius di sekolah. UIN Maliki press.

Sani, R. A., \& Kadri, M. (2016). Pendidikan karakter, mengembangkan karakter anak yang islami. Bumi aksara.

Santrock, J. W. (2017). Perkembangan remaja jilid 2, (terj. shinto d. adelar dan sherly saragy. Erlangga.

Sarwono, S. W. (2013). Psikologi sosial:psikologi kelompok dan psikologi terapan. Cipta karya.

Shabrina, M. N., Azizah, N., Rifqi, M. Z., Anak, P., Dini, U., \& Yogyakarta, U. N. (2020). Jurnal Obsesi : Jurnal Pendidikan Anak Usia Dini Pembelajaran Tahfidz sebagai Media Menumbuhkan Karakter Tanggung Jawab pada Anak Temper Tantrum Abstrak. 4(2), 1099-1111. https://doi.org/10.31004/obsesi.v4i2.511

Silkyanti, F. (2019). Analisis Peran Budaya Sekolah yang Religius dalam Pembentukan Karakter Siswa. Indonesian Values and Character Education Journal, 2(1), 36. https:// doi.org/10.23887/ivcej.v2i1.17941

Sit, M. (2015). Psikologi perkembangan anak usia dini. Perdana publishing.

Sriwilujeng, D. (2017). Panduan implementasi penguatan pendidikan karakter. Erlangga.

Suharni, S. M. E. (2021). Jurnal Obsesi : Jurnal Pendidikan Anak Usia Dini Peran Orangtua terhadap Kesiapan Sekolah Taman Kanak- Kanak pada Anak Usia Dini Abstrak. 5(1), 559-565. https://doi.org/10.31004/obsesi.v5i1.454 
Suparlan. (2012). Mendidik karakter membetuk hati. Ar-Ruzz media.

Towoliu, I. D., \& Hartati, S. (2021). Jurnal Obsesi : Jurnal Pendidikan Anak Usia Dini Pendidikan Karakter Berbasis Islam melalui Program Cinta Rosul pada Anak Taman Kanak-Kanak Abstrak. 5(1), 521-529. https:// doi.org/10.31004/obsesi.v5i1.618

Trimuliana, I., \& Dhieni, N. (2019). Jurnal Obsesi : Jurnal Pendidikan Anak Usia Dini Perilaku Religius Anak Usia 5-6 Tahun pada PAUD Model Karakter. 3(2), 570-577. https://doi.org/10.31004/obsesi.v3i2.251

Utami, F., \& Prasetyo, I. (2021). Pengasuhan Keluarga terhadap Perkembangan Karakter Disiplin Anak Usia Dini. 5(2), 1777-1786. https:// doi.org/10.31004/obsesi.v5i2.985

Wahyuni, S., \& Purnama, S. (2021). Jurnal Obsesi : Jurnal Pendidikan Anak Usia Dini Pengembangan Religiusitas m elalui Metode Kisah Qur ' ani di Abstrak. 5(1), 103 116. https://doi.org/10.31004/obsesi.v5i1.523

Yarmi, G., \& Wardhani, P. A. (2020). Jurnal Obsesi : Jurnal Pendidikan Anak Usia Dini Efektivitas Pengembangan Karakter melalui Fun Garden of Literacy Bagi Anak Usia 7 Tahun Abstrak. 4(2), 1068-1075. https://doi.org/10.31004/obsesi.v4i2.492 